\title{
Plutonium Immobilization or Mobilization: The Contribution of Microbial Products and Cells
}

\author{
NANCY MERINO ${ }^{1 *}$, FANNY MARIE COUTELOT $^{2}$, CONNOR $^{2}$ \\ PARKER ${ }^{2}$, DANIEL I. KAPLAN ${ }^{3}$, ANNIE B. KERSTING ${ }^{1}$, \\ YONGQIN JIAO ${ }^{1}$, BRIAN POWELL ${ }^{2}$, MAVRIK ZAVARIN ${ }^{1}$ \\ ${ }^{1}$ Lawrence Livermore National Laboratory, Livermore, CA, \\ USA (*merino4@1lnl.gov) \\ ${ }^{2}$ Clemson University, Clemson, SC, USA \\ ${ }^{3}$ Savannah River National Laboratory, Aiken, SC, USA
}

Plutonium $(\mathrm{Pu})$ redox cycling is known to occur in stratified lakes and ponds, with higher concentrations occurring in the anoxic layers ${ }^{1}$. This increase of $\mathrm{Pu}$ in the water column likely involves $\mathrm{Pu}$ re-mobilization from the sediment and $\mathrm{Pu}$ immobilization due to complexation with organic carbon and iron minerals. However, the contribution of microorganisms to the environmental fate and transport of $\mathrm{Pu}$ is little understood. In particular, microbial intracellular and extracellular (exudates) products likely provide various metal binding sites for either mobilization or immobilization of actinides. To decipher the role of microorganisms in the biogeochemical cycling of $\mathrm{Pu}$ in aquatic systems, a combination of field and laboratory studies were conducted at Pond B, Savannah River Site (SRS, South Carolina, USA).

Pond $\mathrm{B}$ is a man-made, monomictic reservoir that received reactor cooling water from $\mathrm{R}$ reactor between 19611964 containing trace amounts of ${ }^{238,239,240} \mathrm{Pu},{ }^{241} \mathrm{Am}$, and ${ }^{137} \mathrm{Cs}$. Analysis of monthly water column profiles from our study confirmed seasonal biogeochemical cycling in the pond, including the distribution of redox-sensitive metals and actinides. We also observed shifts in the bacterial community relative abundances with season and depth. Microcosm experiments under various conditions targeted the growth of specific microorganisms (phototrophs, heterotrophs, iron oxidizers, fermenters, and sulfate reducers), which correspond to the likely metabolisms occuring in Pond B. The metal binding capability of the microbial cells, exudates, and intracellular products were tested and compared to assertain the contribution to $\mathrm{Pu}$ mobility. We observed cell densitydependent $\mathrm{Pu}$ sorption that differed with enrichment condition, as well as differential $\mathrm{Pu}$ binding to certain molecular weight size fractions of microbial products. These results demonstrate the role of microorganisms in complexing and immobilizing $\mathrm{Pu}$ in freshwater aquatic systems.

Prepared by LLNL under Contract DE-AC5207NA27344

1. Sholkovitz, E. R. et al. Nature 1982, 300 (5888), 159. 